\title{
Increased expression of A-kinase anchoring proteins in T cells from systemic lupus erythematosus patients
}

\author{
M J Pérez-Lorenzo, M Galindo, A J García-González, G Criado* \\ From 5th European Workshop on Immune-Mediated Inflammatory Diseases \\ Sitges-Barcelona, Spain. 1-3 December 2010
}

\section{Introduction}

Deficient activation of protein kinase A (PKA) is a characteristic of $\mathrm{T}$ cells in systemic lupus erythematosus (SLE). A-kinase Anchoring Proteins (AKAPs) associate to and regulate the activity of PKA [1]. Furthermore, some AKAPs are expressed in T cells and influence their function [2]. Therefore, altered expression and/or function of AKAPs can play a role in the deregulated activity of PKA observed in SLE T cells.

\section{Aims}

To analyse the expression of different AKAPs in T cells isolated from SLE patients.

\section{Patients and methods}

$\mathrm{T}$ cells were isolated by negative selection using magnetic beads from SLE patients $(\mathrm{n}=12)$ and healthy controls $(\mathrm{HC}, \mathrm{n}=12)$. RNA was purified and levels of AKAP79, AKAP95 and AKAP450 mRNA were quantified by RT-qPCR. Subsequently, the analysis of AKAP79 expression was extended to include a total of 24 SLE patients and19 HC. In addition, AKAP79 protein was detected by Western Blot and quantified with Quantity One software.

\section{Results}

Levels of AKAP450 mRNA were comparable in $\mathrm{HC}$ and SLE T cells $(10.73+/-0.73(\mathrm{HC}, \mathrm{n}=12)$ vs $12.69+/$ 1.09 (SLE, $\mathrm{n}=12$ ), $\mathrm{P}=0.15$ ). However, $\mathrm{T}$ Cells from SLE patients had significantly higher levels of AKAP79 and AKAP95 mRNA than HC (AKAP79: $1.99+/-0.29$ $(\mathrm{HC}, \mathrm{n}=19)$ vs $3.61+/-0.72(\mathrm{SLE}, \mathrm{n}=24), \mathrm{P}=0.04$;

Centro de Investigación y Servicio de Reumatología, Hospital 12 de Octubre, Instituto de Investigación Sanitaria "I + 12", Madrid, Spain
AKAP95: $2.58+/-0.18(\mathrm{HC}, \mathrm{n}=12)$ vs $4.13+/-0.31$ (SLE, $\mathrm{n}=12$ ), $\mathrm{P}=0.0005)$. Analysis of AKAP79 protein levels showed increased levels of AKAP79 in SLE T cells compared to $\mathrm{HC} \mathrm{T}$ cells $(0.38 \pm 0.05(\mathrm{HC})$ vs $0.75 \pm$ 0.18 (SLE), $\mathrm{P}=0.06$ ).

\section{Conclusions}

Increased levels of AKAP79 and AKAP95 in T cells from SLE patients can contribute to the deregulation of PKA activity in these cells.

Published: 25 November 2010

\section{References}

1. Jarnaess E, Taskén K: Spatiotemporal control of cAMP signalling processes by anchored signalling complexes. Biochem Soc Trans. 2007, 35:931-7.

2. Schillace RV, Carr SD: The role of Protein Kinase A and A Kinase Anchoring proteins in modulating $T$ cell activation: Progress and future directions. Crit Rev Immunol 2006, 26:113-31.

\section{doi:10.1186/1479-5876-8-S1-P49}

Cite this article as: Pérez-Lorenzo et al:: Increased expression of A-kinase anchoring proteins in $\mathrm{T}$ cells from systemic lupus erythematosus patients. Journal of Translational Medicine 2010 8(Suppl 1):P49.

Submit your next manuscript to BioMed Central and take full advantage of:

- Convenient online submission

- Thorough peer review

- No space constraints or color figure charges

- Immediate publication on acceptance

- Inclusion in PubMed, CAS, Scopus and Google Scholar

- Research which is freely available for redistribution 